\title{
PENGENDALIAN HAYATI PENYEBAB PENYAKIT REBAH SEMAI Fusarium subglutinans DENGAN Trichoderma harzianum
}

\author{
Biological Control of Damping Off Disease Caused by Fusarium subglutinans using \\ Trichoderma harzianum
}

\author{
M. Christita ${ }^{1)}$, S. M. Widyastuti ${ }^{2)}$, dan H. Djoyobisono ${ }^{2)}$ \\ 1) Balai Penelitian Kehutanan Manado \\ Jl.Raya Adipura, Kima Atas, Mapanget, Manado \\ Email : mchristita@gmail.com \\ 2) Fakultas Kehutanan, Universitas Gadjah Mada \\ Jl.Agro, Bulak Sumur, Yogyakarta
}

\begin{abstract}
The mortality of pine seedling in nursery was caused by damping off. Damping off disease is caused by soil borne pathogenic fungus Fusarium subglutinans. To get an effective method in controlling the diseases, is important to understand the effectiveness of biocontrol agent Trichoderma harzianum. The purpose of this research was to comprehend the inhibition mechanism of $\mathrm{T}$. harzianum against $\mathrm{F}$. subglutinans and its effectiveness. The research methods include (1) in vitro application of T. harzianum with Green Fluorescent Protein [GFP] using dual culture method, and (2) in planta application by inoculating T. harzianum with GFP four days before $\mathrm{F}$. subglutinans inoculation, inoculating $\mathrm{T}$. harzianum and $\mathrm{F}$. subglutinans at the same time, and inoculating of $\mathrm{T}$. harzianum four days after $\mathrm{F}$. subglutinans inoculation. The results of this research showed that Trichoderma harzianum is effective to inhibit the growth of F. subglutinans in planta. The mechanism of T.harzianum to inhibit the growh of F.subglutinans is by nutrient competition.
\end{abstract}

\section{Keywords: Damping off, Fusarium subglutinans, Pinus merkusii, Trichoderma harzianum}

\begin{abstract}
ABSTRAK
Salah satu penyebab kematian tanaman Pinus di persemaian adalah penyakit rebah semai. Penyakit rebah semai disebabkan oleh patogen tular tanah yaitu jamur Fusarium subglutinans. Untuk mendapatkan metode yang efektif dalam mengendalikan penyakit rebah semai, perlu diketahui efektivitas agen pengendali hayati yaitu Trichoderma harzianum.Tujuan dari penelitian ini adalah untuk mengetahui respon ketahanan semai tusam terhadap infeksi $F$. Subglutinans dan mekanisme penghambatan T.harzianum terhadap perkembangan F.subglutinans. Metode yang digunakan dalam penelitian ini adalah (1) uji in vitro T. harzianum yang mengekspresikan Green Fluorescent Protein [GFP] dengan menggunakan metode dual culture, dan (2) uji in planta dengan inokulasi $T$. harzianum GFP empat hari sebelum inokulasi $F$. subglutinans, inokulasi T. harzianum dan F. subglutinans bersamaan, dan inokulasi T. harzianum empat hari setelah inokulasi $F$. subglutinans. Hasil penelitian menunjukkan Trichoderma harzianum efektif untuk menghambat perkembangan $F$. subglutinans in planta. Mekanisme penghambatan T.harzianum terhadap F.subglutinans adalah dengan cara kompetisi nutrisi.
\end{abstract}

\section{Kata kunci: Fusarium subglutinans, Pinus merkusii, rebah semai, Trichoderma harzianum}




\section{PENDAHULUAN}

Pinus merkusii atau selanjutnya disebut tusam merupakan jenis tanaman yang banyak dimanfaatkan dalam pengembangan Hutan Tanaman Industri (HTI) terutama di Sumatera dan Jawa. Kualitas semai yang baik adalah hal yang mendasari keberhasilan penanaman tusam. Salah satu penyebab kegagalan penyediaan semai tusam yang baik adalah penyakit rebah semai. Penyakit rebah semai menyebabkan kematian semai dalam waktu yang singkat, batang semai yang terserang akan membusuk sehingga roboh dan mati. Rebah semai dapat disebabkan oleh beberapa jamur patogen antara lain Phytophthora, Pythium, Rhizoctonia, dan Fusarium. Jamur Fusarium spp. merupakan patogen paling umum yang menyebabkan terjadinya rebah semai pada semai tusam (Widyastuti, 1996).

Untuk mengurangi kerugian akibat penyakit rebah semai, dilakukan penerapan konsep pengendalian penyakit tanaman terpadu (integrated disease management) (Besri, 1998). Konsep pengendalian penyakit terpadu antara lain dengan teknik pengendalian secara budidaya, penggunaan varietas tahan, dan penggunaan bahan kimia. Pencegahan penyakit rebah semai yang disebabkan oleh patogen in situ dapat dilakukan antara lain dengan cara pemilihan benih yang baik, sterilisasi media, dan pemeliharaan semai yang baik (Cram, 2004). Penanggulangan penyakit yang telah banyak dilakukan adalah dengan pemberian fungisida. Selain pemberian fungisida, dikembangkan pula alternatif pencegahan penyakit dengan pemanfaatan pengendali hayati. Salah satu jamur yang efektif sebagai pengendali hayati adalah T. harzianum (Hjeljord dan Trosmo,1998). Trichoderma harzianum selain diharapkan efektif sebagai pengendali hayati juga digunakan untuk mengetahui interaksi dan mekanisme penghambatannya terhadap $F$. subglutinans. Tidak hanya pada tanaman kehutanan, peran Trichoderma harzianum sebagai pengendali hayati juga telah terbukti untuk mengatasi patogen pada tanaman tembakau ( Gveroska dan J. Ziberoski, 2012).

Tujuan dilakukannya penelitian ini adalah untuk mengetahui respon ketahanan semai tusam terhadap infeksi $F$. Subglutinans dan mekanisme penghambatan perkembangan $F$. subglutinans oleh $T$. harzianum. 


\section{METODE PENELITIAN}

\section{A. Bahan Penelitian}

Pada penelitian ini digunakan semai tusam (P. merkusii) mulai umur satu hari yaitu pada awal semai berkecambah. Mikroorganisme yang digunakan pada penelitian ini adalah (1) F. subglutinans diisolasi dari tusam yang menunjukkan gejala rebah semai, (2) T. harzianum GFP (Green Fluorescent Protein), yaitu T.harzianum yang telah mengalami rekayasa genetik berupa insersi gen perbendar dan (3) T. harzianum wildtype (spesies alami $T$. harzianum yang tidak mengalami rekayasa genetik). Trichoderma harzianum GFP dan $T$. harzianum wildtype adalah koleksi Dr. Agus Purwantara (Balai Penelitian Bioteknologi Perkebunan Indonesia-Bogor). Isolat murni diperbanyak dengan menumbuhkan $T$. harzianum GFP pada cawan Petri dengan diameter $9 \mathrm{~cm}$. Media yang digunakan adalah Potato Dextrose Agar (PDA).

\section{B. Tempat dan Waktu Penelitian}

Penelitian dilakukan di: (1) Laboratorium Perlindungan dan Kesehatan Hutan, Fakultas Kehutanan, Universitas
Gadjah Mada, (2) Laboratorium Struktur dan Anatomi Kayu, Jurusan Teknologi Hasil Hutan, Fakultas Kehutanan, Universitas Gadjah Mada, dan (3) Laboratorium Penelitian dan Pengujian Terpadu, Universitas Gadjah Mada.

Penelitian dilakukan pada bulan Desember 2008 sampai dengan Februari 2010.

\section{Metode Penelitian}

Prosedur penelitian dijelaskan dalam diagram alur penelitian pada Gambar 1.

\section{Uji Ketahanan Hidup Semai Tusam}

Tingkat ketahanan hidup semai tusam diukur dengan perhitungan persentase semai tusam hidup. Persentase semai tusam hidup dihitung dengan inokulasi $F$. subglutinans terhadap semai tusam sesuai perlakuan yang telah ditentukan, yaitu dengan aplikasi T. harzianum baik GFP maupun jenis wildtype-nya, serta tanpa aplikasi GFP. Trichoderma harzianum wildtype digunakan untuk mengetahui efektifitasnya dalam menghambat $F$. Subglutinans di dalam tanah dibandingkan dengan T. harzianum GFP yang telah mengalami rekayasa genetik. 


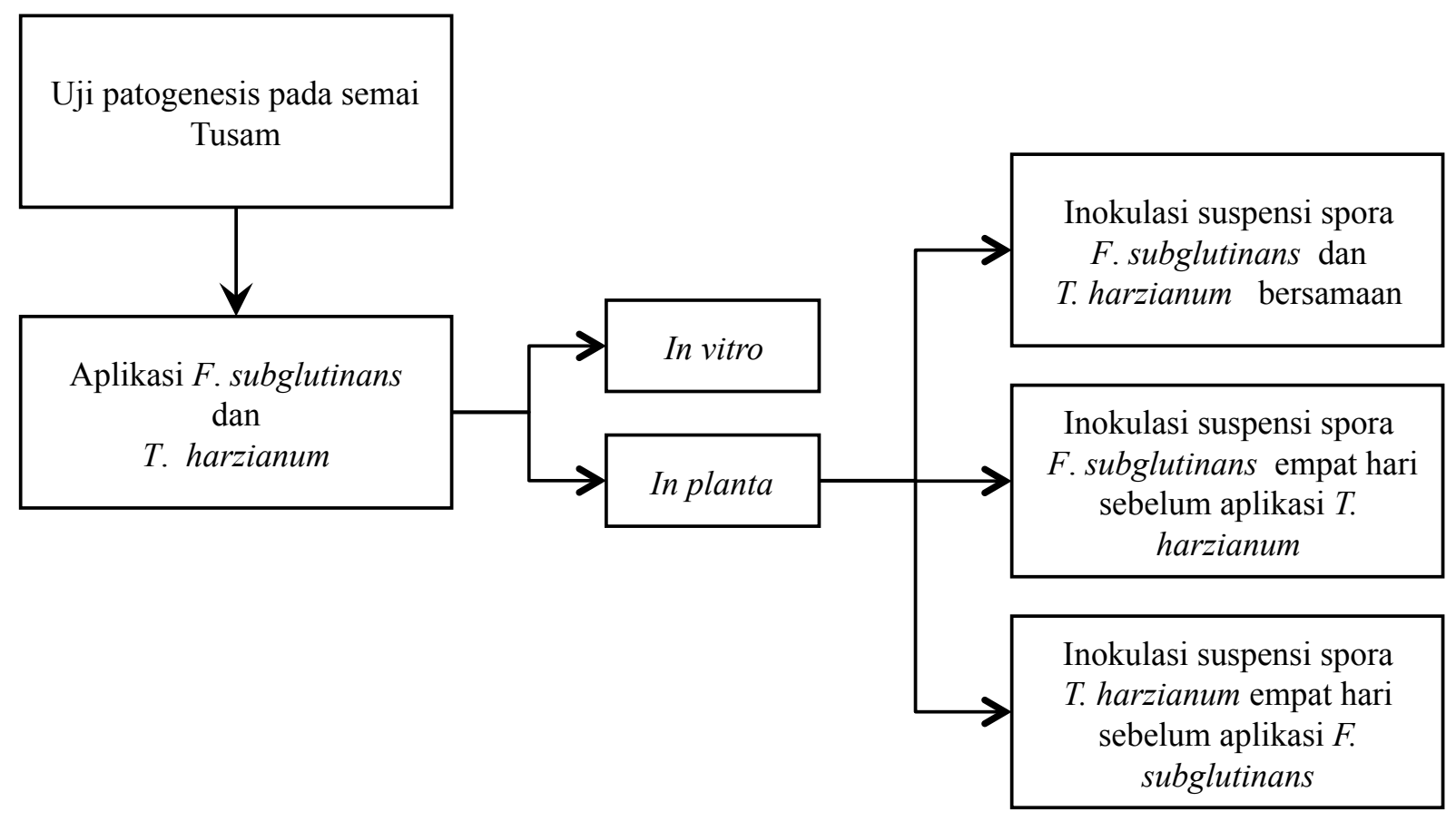

Gambar 1. Diagram alur kegiatan penelitian

Setiap penanaman disertai dengan kontrol. Untuk melakukan uji tingkat ketahanan hidup semai tusam diterapkan perlakuan sebagai berikut (Gambar 2):

1. Semai tusam dengan inokulasi $F$. subglutinans

2. Kontrol berupa semai tusam

3. Semai tusam dengan aplikasi $F$. subglutinans dan T. harzianum GFP dan T.harzianum wildtype dengan 3 perlakuan, masing-masing:

a. Aplikasi T. harzianum GFP atau wildtype empat hari sebelum aplikasi F. subglutinans. (dua hari sebelum penanaman semai tusam)

b. Aplikasi F. subglutinans empat hari sebelum aplikasi T. harzianum GFP atau wildtype (dua hari sebelum aplikasi penanaman semai tusam)

c. Aplikasi F. subglutinans dan $T$. harzianum GFP atau wildtype bersamaan

Masing-masing perlakuan diterapkan dengan menanam satu pot (diameter $10 \mathrm{~cm}$ ) berisi 15 semai yang akan mendapat perlakuan inokulasi patogen dan aplikasi pengendali hayati, serta satu pot berisi 15 semai yang digunakan sebagai kontrol. Untuk dapat menyebabkan penyakit rebah semai diperlukan suspensi spora $F$. subglutinans sebesar $4.8 \times 10^{6}$ spora $/ \mathrm{mL}$ untuk model infeksi pada 10 batang semai (Zad dan Koshnevice, 2001). 


\section{Semai Tusam

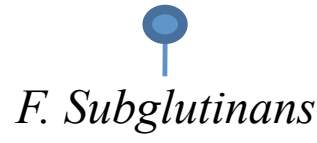

\section{T. harzianum}

-2 hari

T. harzianum

-2 hari

F. subglutinans
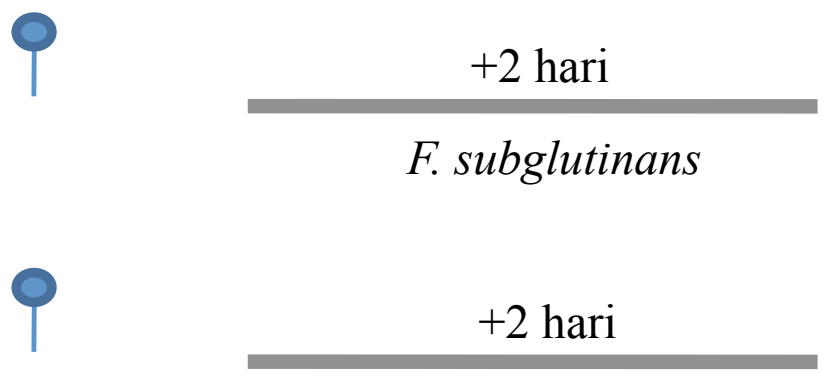

T. harzianum

\section{Gambar 2. Ilustrasi perlakuan uji ketahanan hidup semai tusam}

Berdasarkan pustaka dan uji pendahuluan maka, pada penelitian ini digunakan rata-rata kerapatan suspensi spora F. subglutinans sebesar $2,53 \times 10^{8}$ spora/ mL untuk inokulasi. Sebagai pengendali hayati diinokulasikan T. harzianum dengan kerapatan spora 1-5 x 105 spora/mL (McLean et al., 2001). Pada penelitian ini dilakukan aplikasi T. harzianum GFP dengan kerapatan suspensi spora rata-rata sebesar $1,96 \times 10^{8}$ spora/mL, sedangkan aplikasi dengan $T$. harzianum wildtype menggunakan suspensi spora dengan kerapatan rata-rata $1,81 \times 10^{8}$ spora/mL.

Berdasarkan hasil inokulasi pada tiga pola penanaman tersebut, dilakukan pengamatan pada hari pertama semai mengalami rebah hingga hari terakhir semai rebah seluruhnya. Berdasarkan uji pendahuluan yang telah dilakukan, pada hari ke-15 semua semai mengalami kematian.

\section{E. Uji Daya Hambat Trichoderma harzianum In Vitro}

Uji daya hambat pengendali hayati secara in vitro dilakukan dengan metode dual culture (Abaysinghe, 2007; Coskuntuna dan Ozer, 2008; Ghildival dan Pandev, 2008) Uji dual culture untuk pengamatan mikroskopis dan untuk perhitungan persentase daya hambat dilakukan dengan cara yang berbeda.

Penghitungan persentase daya hambat dilakukan dengan melakukan pengamatan 
dan perhitungan luas koloni $F$. subglutinans satu hari setelah penananaman T. harzianum. Untuk dapat menghitung persentase daya hambat dilakukan penanaman metode dual culture tanpa menggunakan gelas benda dan satu cawan Petri F. subglutinans sebagai kontrol. Ilustrasi metode dapat dilihat pada Gambar 3. Efektivitas penghambatan dapat dihitung dengan mengetahui ukuran penutupan luasan jamur $F$. subglutinans pada cawan Petri dengan mengikuti persamaan
(Ghildival dan Pandev, 2008). Rata-rata luas koloni dihitung setiap hari dimulai pada hari keenam setelah penanaman $F$. subglutinans atau hari ketiga setelah penanaman $T$. harzianum:

$$
C=\frac{a-b}{a} \times 100 \%
$$

Keterangan :

a : Rata-rata luas kontrol (koloni $F$. subglutinans)

b : Rata-rata luas koloni $F$. subglutinans dengan T. harzianum

C : Daya hambat T. Harzianum

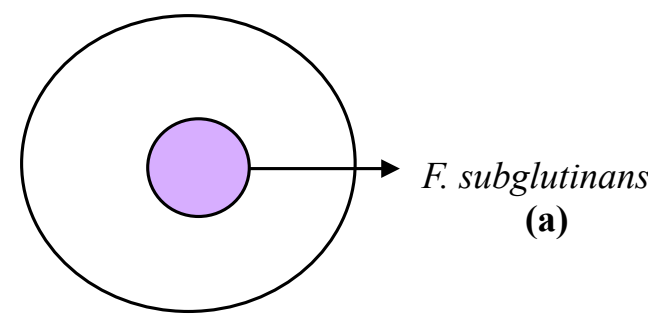

A

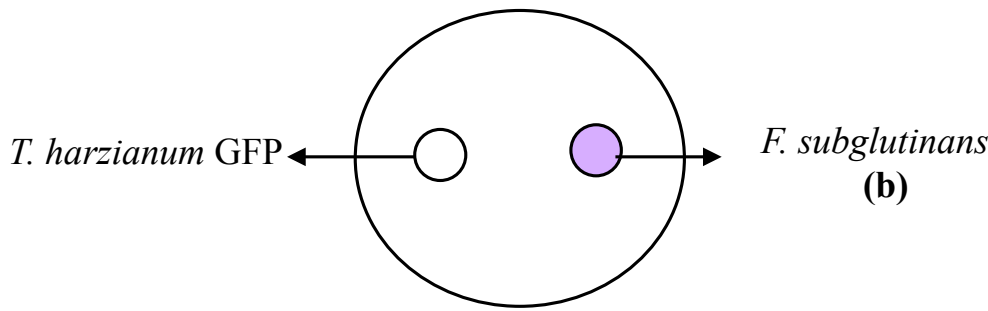

B

Gambar 3. Ilustrasi metode uji penentuan persen daya hambat Trichoderma harzianum GFP terhadap Fusarium subglutinans. (A) F. subglutinans control (B) Dual culture T. harzianum GFP dengan F. subglutinans

Pada penanaman dengan metode dual culture untuk kepentingan pengamatan mikroskopis, $F$. subglutinans dan $T$. harzianum GFP ditanam dalam satu cawan Petri dengan posisi yang saling berhadapan.
Penanaman ini dilakukan pada cawan Petri (diameter $9 \mathrm{~cm}$ ), dengan media PDA dan gelas benda di tengahnya yang akan digunakan untuk pengamatan mikroskopis. Berdasarkan uji pendahuluan, $F$. 
subglutinans tumbuh lebih lambat sehingga

penanaman T. harzianum GFP (Gambar 4).

ditumbuhkan tiga hari lebih awal sebelum

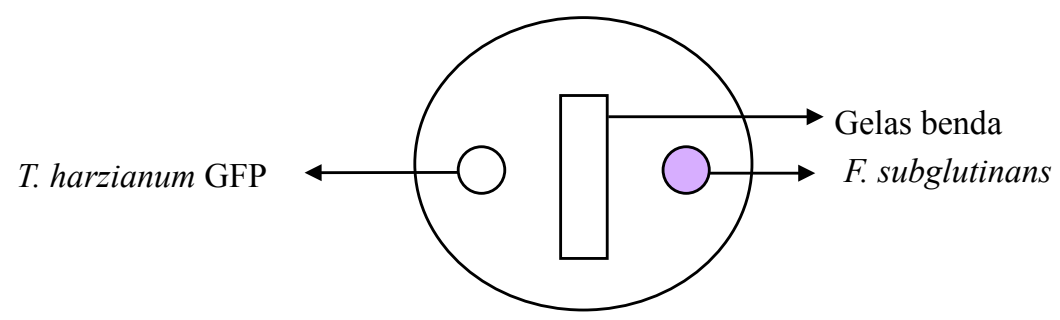

Gambar 4. Ilustrasi metode uji daya hambat in vitro menggunakan metode dual culture

Pada metode dengan penambahan gelas benda di tengah cawan Petri dilakukan prosedur sterilisasi menggunakan autoclave. Gelas benda lebih dulu dimasukkan ke dalam cawan Petri, kemudian cawan Petri beserta gelas benda disterilisasi dengan menggunakan autoclave. Pada saat siap digunakan, cawan Petri yang telah dilengkapi dengan gelas benda dituangi PDA sebagai media pertumbuhan jamur.

\section{HASIL DAN PEMBAHASAN}

\section{A. Uji Pengendalian Hayati dengan Trichoderma harzianum}

Interaksi antagonis yang dilakukan oleh jamur Trichoderma spp. sebagai pengendali hayati bertujuan untuk menghambat pertumbuhan jamur lain. Mekanisme antagonistik yang dilakukan oleh Trichoderma sp. yaitu antibiosis, mikoparasitisme, dan kompetisi untuk memperebutkan nutrisi (Hjeljord dan Trosmo, 1998). Berdasarkan perhitungan besar penutupan luas pertumbuhan jamur patogen oleh T. harzianum, dilakukan perhitungan persen daya hambat seperti di sajikan pada Gambar 5. Perhitungan persen daya hambat dimulai sejak pertama kali miselia jamur tampak menyatu yaitu pada hari keenam setelah jamur F. subglutinans ditanam di dalam cawan Petri. Hari pertama yang disajikan dalam grafik adalah hari pertama jamur bertemu atau saling menyentuh.

Daya hambat T. harzianum terhadap F. subglutinans meningkat dengan pertambahnya penutupan luasan jamur patogen oleh T. harzianum. Sejak hari pertama kedua hifa jamur bertemu, persen penutupan cawan Petri oleh T. harzianum semakin meningkat. Hari keempat setelah hifa saling menyentuh persen penghambatan 


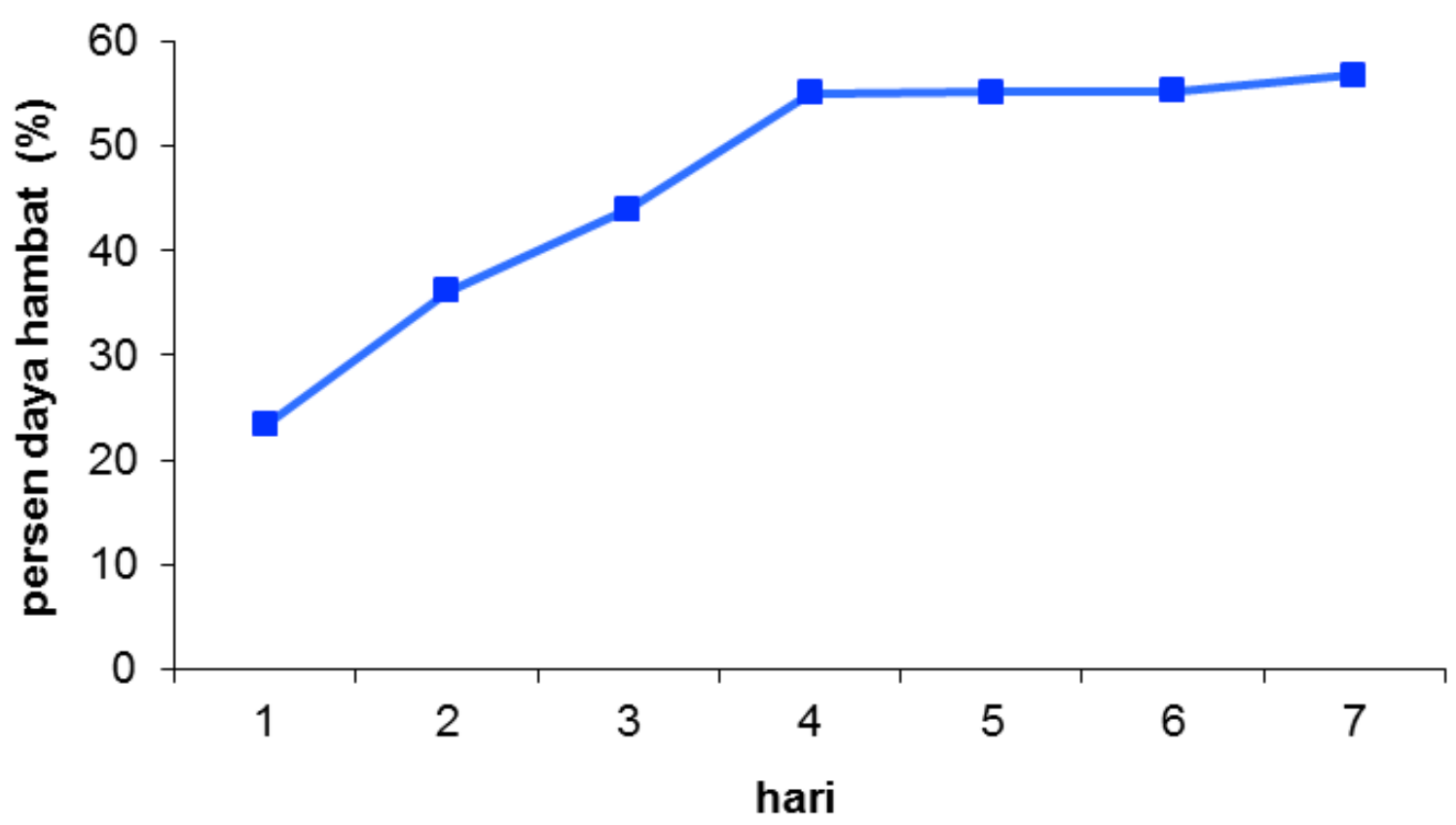

Gambar 5. Daya hambat Trichoderma harzianum terhadap Fusarium subglutinans.

Perbedaan kenampakan makroskopis dan mikroskopis antara T. harzianum GFP dan T. harzianum wildtype dapat dilihat pada Gambar 6. Biakan murni T. harzianum GFP memiliki warna hijau hingga kekuningan pada media PDA (Potato Dextrose Agar) hal tersebut tidak berbeda dengan kenampakan yang ditunjukkan oleh T. harzianum wildtype. Secara mikroskopis T. harzianum GFP akan menunjukkan perbedaan warna jika dibandingkan dengan jenis wildtype yaitu hifanya akan tampak berpendar jika dilihat di bawah mikroskop fluoresen.
Biakan murni T. harzianum wildtype memiliki warna yang sama dengan $T$. harzianum GFP yaitu hijau hingga kekuningkuningan, sedangkan secara mikroskopis hifanya tidak berpendar meskipun dilihat dengan mikroskop fluoresen. Kelebihan mikroorganisme dengan GFP telah banyak dimanfaatkan sebagai alat bantu penelitian terutama sebagai reporter spesies terhadap kasus patogenisitas pada tanaman (Chiu et $a l ., 1996)$. Sifat spesies GFP yang mampu berpendar di bawah mikroskop fluoresen juga telah digunakan pada penelitian monitoring 
pertumbuhan dan aktifitas jamur patogen

di dalam tanah (Bae dan Knudsen, 2000).

Penelitian ini juga sejalan dengan penelitian
Kowsari, 2014 yang menggunakan GFP pada

Trichoderma harzianum untuk mengetahui aktivitas biocontrol tersebut.

A
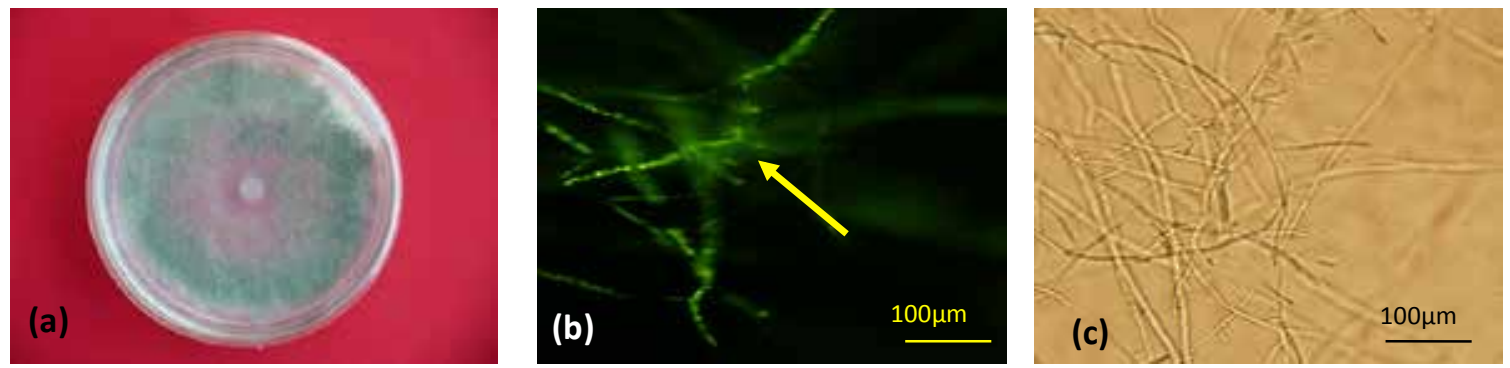

B
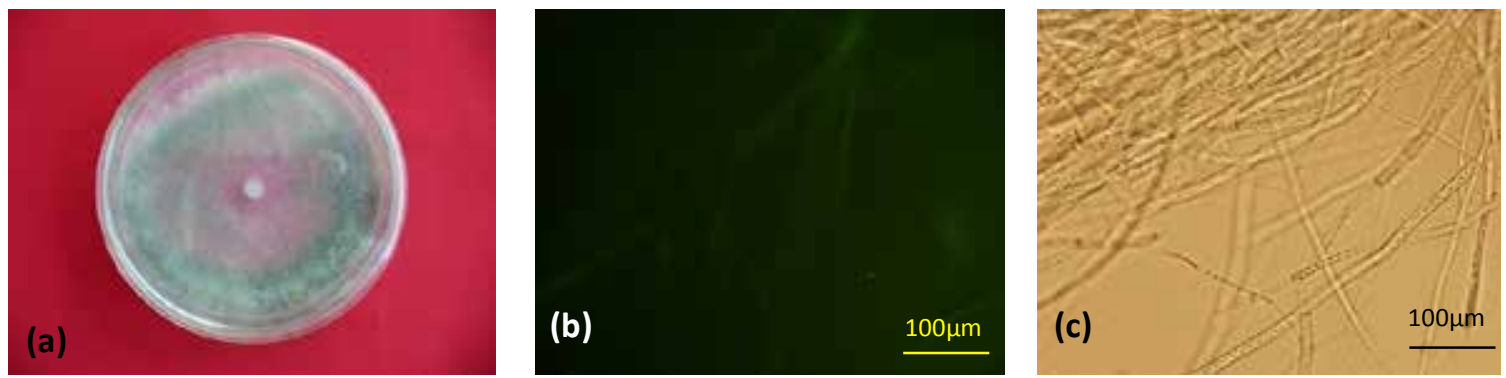

Gambar 6. (A) Trichoderma harzianum GFP. (B) T. harzianum wildtype.

Uji daya hambat $T$. harzianum terhadap F. subglutinans dilakukan dengan uji dual culture. Uji dual culture juga dimaksudkan untuk mengetahui kemampuan T. harzianum sebagai pengendali hayati. Perlakuan dual culture dengan menanam kedua jenis jamur tersebut di dalam satu petri dengan posisi saling berlawanan, dapat dilihat pada Gambar 7a. Secara makroskopis akan terlihat perbedaan warna yang mencolok. Jamur T. harzianum akan lebih cepat memenuhi cawan Petri dan memiliki warna kuning kehijauan. Jamur F. subglutinans meskipun ditanam lebih awal akan tumbuh lebih lambat dan berwarna ungu.

Berdasarkan pengamatan mikroskopis tidak tampak adanya pola pelilitan yang dilakukan hifa T. harzianum terhadap hifa $F$. subglutinans. Pada Gambar 8 dapat dilihat bahwa kedua hifa hanya tampak tumbuh berdampingan dan saling menempel. Diduga pola penghambatan menggunakan mekanisme kompetisi nutrisi. Pertumbuhan F. subglutinans terhambat karena kecepatan tumbuhnya lebih lambat dibandingkan dengan jamur T. harzianum. 

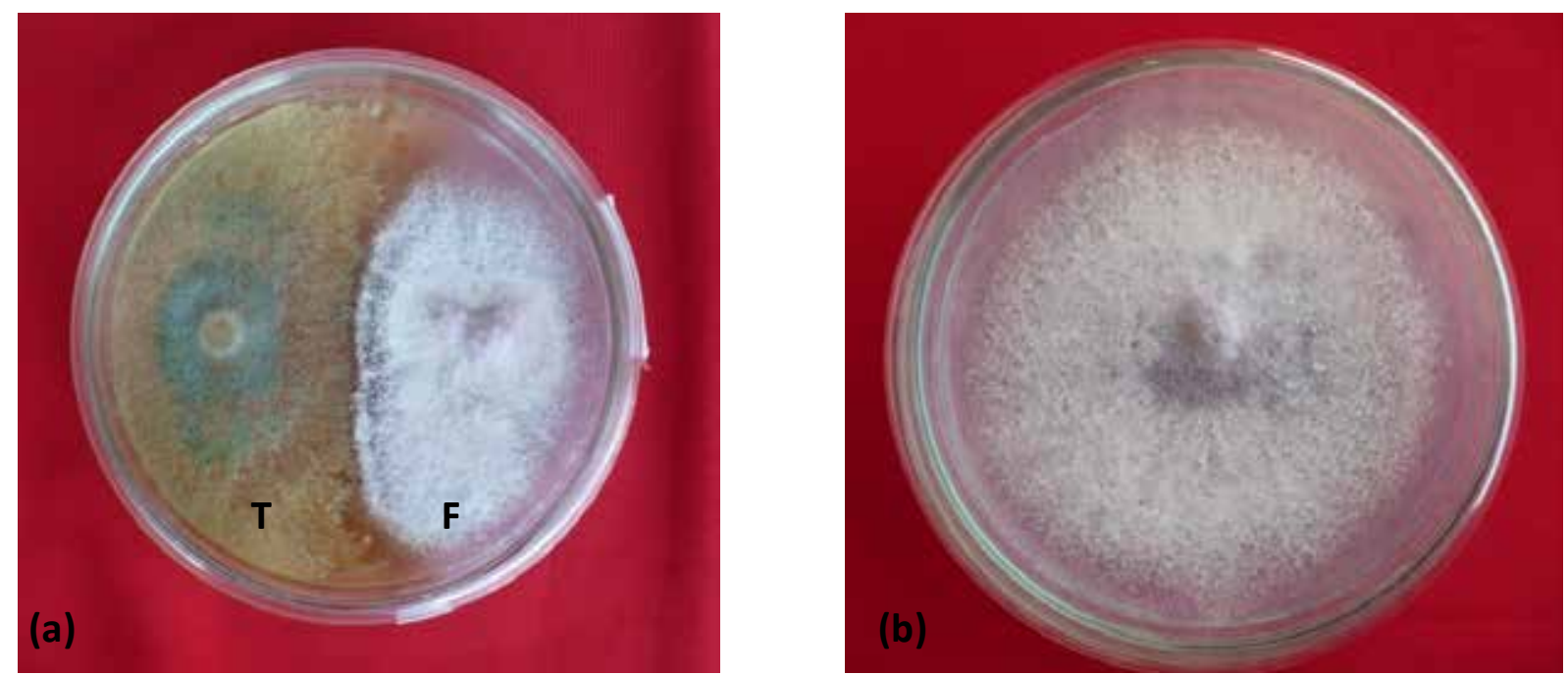

Gambar 7. Gambar 7. (a) Uji dual culture Trichoderma harzianum GFP terhadap Fusarium subglutinans 12 hari pada media PDA. T. harzianum (T), F. subglutinans (F) (b) biakan murni $F$. subglutinans sebagai kontrol berusia 12 hari dalam media PDA.

Selain kompetisi nutrisi, mekanisme mikoparasit oleh T. harzianum adalah dengan menghasilkan senyawa racun (mycotoxin). Trichoderma harzianum telah diketahui menghasilkan trichorzins dan harzianins (Vey et al., 2001). Kedua jenis senyawa

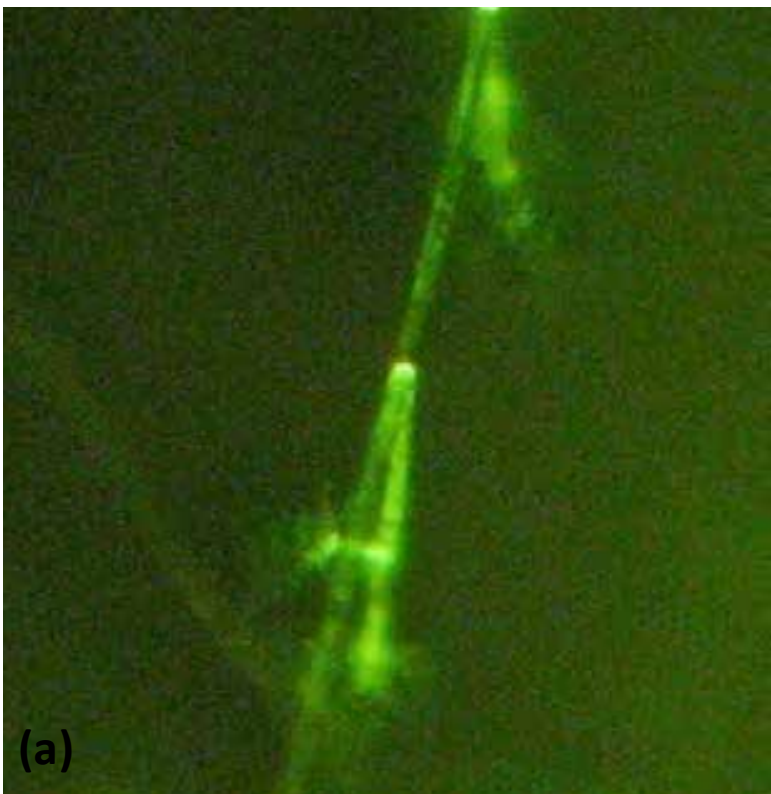

tersebut merupakan senyawa metabolit sekunder yang diduga menghambat pertumbuhan jamur patogen karena bersifat antibiosis (Hajieghrari et al., 2008; Vey et al., 2001)

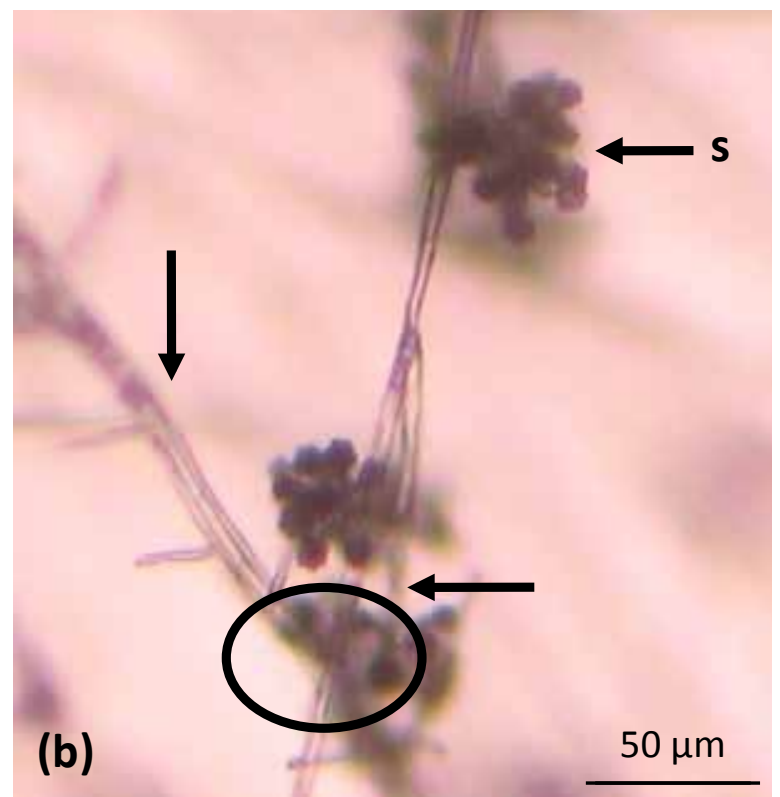

Gambar 8. Interaksi Trichoderma harzianum GFP dengan Fusarium subglutinans pada media PDA. (a) Pengamatan dengan mikroskop fluoresen. Hifa T. harzianum GFP yang berpendar (anak panah). (b) Pengamatan dengan mikroskop cahaya. Hifa F. Subglutinans (anak Panah). Penempelan hifa $F$. subglutians dan T. harzianum GFP (lingkaran). Spora (anak panah s). 
Pemanfaatan T. harzianum GFP sebagai pengendali hayati sangat berguna untuk mempelajari mekanisme penghambatan perkembangan $F$. subglutinans pada semai tusam. Keistimewaan T. harzianum GFP mempermudah pengamatan proses pengendalian hayati. Dengan memanfaatkan T.harzianum tidak lagi dimerlukan proses fiksasi jaringan tetapi cukup dengan pengamatan menggunakan mikroskop.

\section{B. Ketahanan Hidup Semai Tusam}

Setelah dilakukan uji in planta yaitu inokulasi patogen $F$. subglutinans pada semai tusam diketahui bahwa terjadi respon yang berbeda antara masing-masing perlakuan. Grafik persentase semai tusam hidup dengan aplikasi T. harzianum GFP serta T. harzianum wildtype disajikan pada Gambar 9.

Pada perlakuan penanaman semai tusam dengan aplikasi $F$. subglutinans dan T. harzianum GFP sebagai pengendali hayati diketahui perlakuan yang paling tinggi persentase hidupnya adalah dengan aplikasi T. harzianum GFP empat hari sebelum aplikasi F. subglutinans. Pada perlakuan tersebut, T. harziamun GFP diaplikasikan terlebih dulu yaitu dua hari sebelum penanaman semai tusam dan patogen $F$. subglutinans diinokulasikan dua hari setelah penanaman semai tusam. Perlakuan seperti ini memungkinkan spora $T$. harzianum GFP menyebar lebih dulu di tanah dan jaringan semai sehingga menghambat perkembangan patogen F. subglutinans. Persentase hidup terendah terjadi pada perlakuan penanaman Tusam dengan aplikasi patogen $F$. subglutinans empat hari sebelum aplikasi T. harzianum, hal ini disebabkan hifa $F$. subglutinans telah masuk dan menyebar ke dalam jaringan semai, sehingga lebih cepat merusak jaringan sebelum kehadiran pengendali hayati.

Pada perlakuan penanaman semai dengan aplikasi $T$. harzianum wildtype dihasilkan persen hidup tertinggi terdapat pada perlakuan dengan aplikasi T. harziamun wildtype lebih dua hari sebelum penanaman semai tusam. Persentase hidup terendah terdapat pada pola penanaman dengan aplikasi $F$. subglutinans dua hari sebelum penanaman semai tusam. Berdasarkan gambar dapat dilihat bahwa baik aplikasi T.harzianum GFP maupun wildtype, efektifitas penghambatan lebih baik pada aplikasi biokontrol sebelum penanaman semai. 
Pada penelitian ini dapat dibuktikan bahwa efektifitas $T$. harzianum menjadi lebih baik jika aplikasi penyebaran inokulasi pada tanah dilakukan sebelum penanaman semai tusam. Kematian seluruh semai pada akhir percobaan disebabkan karena
F. subglutinans bersifat sangat patogenik terhadap semai tusam, dan semai tusam masih terlalu muda sehingga respon ketahanan yang dihasilkan belum optimal dan tidak mampu menghambat laju infeksi patogen.

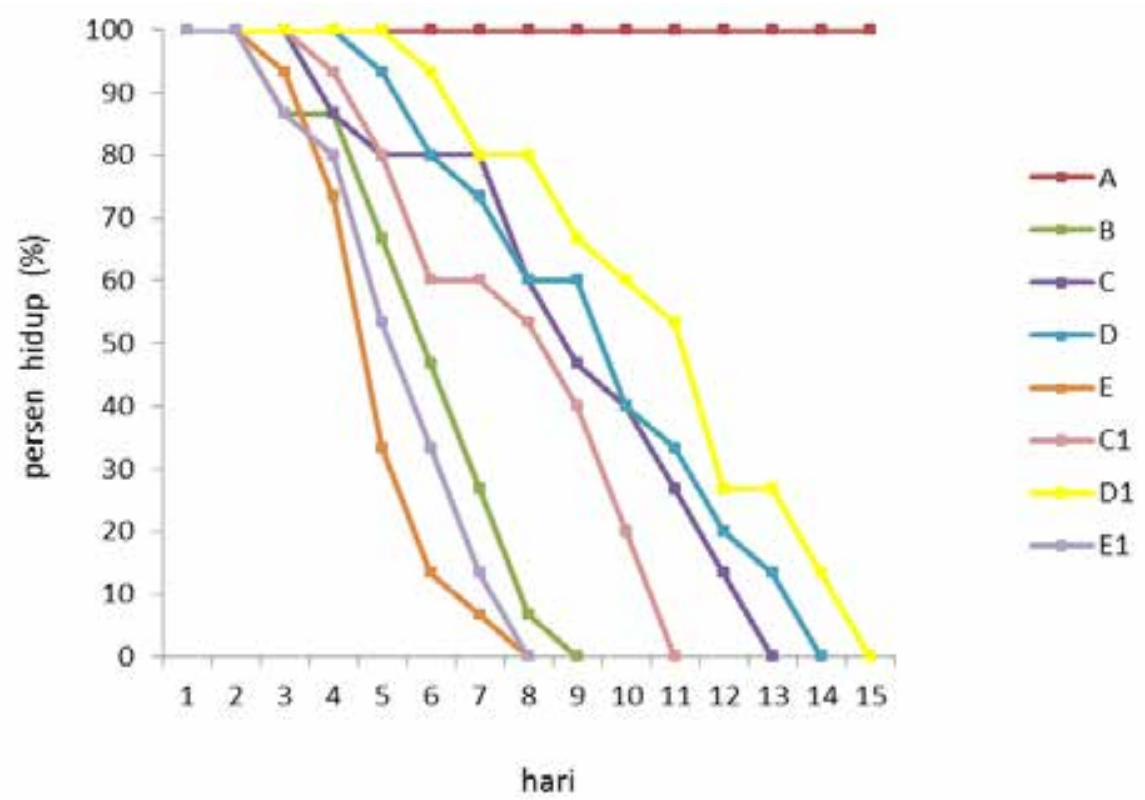

Gambar 9. Persentase hidup semai tusam (Pinus merkusii) dengan aplikasi Fusarium subglutinans, Trichoderma harzianum GFP dan T. harzianum wildtype. Semua semai mati pada hari ke 15.

\section{A : kontrol}

$\mathrm{B}$ : aplikasi $F$. subglutinans

C : aplikasi F. subglutinans dan T. harzianum GFP bersamaan.

D : aplikasi T. harzianum GFP empat hari sebelum aplikasi F. Subglutinans (dua hari sebelum penanaman semai tusam).

E : aplikasi $F$. subglutinans empat hari sebelum aplikasi T. harzianum GFP (dua hari sebelum penanaman semai tusam).

C1 : aplikasi $F$. subglutinans dan T. harzianum wildtype bersamaan

D1 : aplikasi T. harzianum wildtype empat hari sebelum aplikasi F. Subglutinans (dua hari sebelum penanaman semai tusam).

E1 : aplikasi $F$. subglutinans empat hari sebelum aplikasi T. harzianum wildtype(dua hari sebelum penanaman semai tusam). 


\section{KESIMPULAN}

\section{Pada penelitian ini T.harzianum}

terbukti efektif untuk menghambat perkembangan F.subglutinans in planta.

Mekanisme penghambatan T.harzianum

terhadap F.subglutinans adalah dengan cara kompetisi nutrisi.

\section{UCAPAN TERIMAKASIH}

Penelitian ini dilakukan dengan menggunakan dana Hibah bersaing XVII tahun 2010. Terimakasih disampaikan kepada teman-teman Laboratorium Perlindungan dan Kesehatan Hutan, Fakultas Kehutanan Universitas Gadjah Mada atas segala partisipasi dan bantuan dalam melakukan penelitian ini.

\section{DAFTAR PUSAKA}

Abaysinghe S. 2007. Biological Control of Fusarium solani f. sp.phaseoli the Causal Agent of Root Rot of Bean Using Bacillus subtilis CA32 and Thrichoderma harzianum RU 01. Ruhuna Journal of Science 2: 82-88.

Bae Y.S. dan G.R. Knudsen 2000. Cotransformation of Trichoderma harzianum with 3-Glucuronidase and Green Fluorescent Protein Genes Provides a Useful Tool for Monitoring Fungal Growth and Activity in Natural Soils. Applied and Environmental Microbiology 66: 810-815.

Besri M. 1998. Integrated Disease Management in Protected Vegetables Crops in Marocco: Problems and Management Strategies. Cahiers Options Mediterraneenne. Ciheam, Maroko, pp 457-465.

Chiu W., Y. Niwa., W Zeng., T. Hirano., H. Kobayashi, dan J. Sheen. 1996. Engineered GFP as a Vital Reporter in Plants. Current
Biology 6: 325-330.

Coskuntuna A. dan N. Ozer. 2008. Biological Control of Union Basal Root Disease Using Trichoderma harzianum and Induction of Antifungal Compounds in Onion Set Following Seed Treatment. Crop Protection 27: 330-336.

Cram M.M. 2004. Damping off. USDA Forest service, Athens.

Ghildival A. dan A. Pandev. 2008. Isolation of Cold Tolerant Antifungal Strains of Trichoderma sp. from Glacial Sites of Indian Himalayan Region. Research Journal of Microbiology 3: 559-564.

Gveroska Biljana dan J.Ziberoski.2012.Trichoderma harzianum as a Biocontrol Agent Against Alternata on Tobacco. Applied Technologies and Innovation 2: 67-76.

Hajieghrari B., M. Torabi-Giglou., M.R. Mohammadi., dan M. Davari. 2008. Biological Potantial of Some Iranian Trichoderma Isolates in the Control of Soil Borne Plant Pathogenic Fungi. African Journal of Biotechnology 7: 967-972.

Hjeljord L. dan A. Trosmo. 1998. Trichoderma and Glioclaudium in Biological Control : an Overview. Dalam: G.E. Harman dan C.P. Kubicek. (eds) Trichoderma and glioclaudium Taylor \& Francis Ltd, London.

Kowsari, Majegan dan M. Matatebi.2014. Contruction of New GFP-Target Fusant for Trichoderma harzianum with Enhanced Biocontrol Activity. Journal of Plant Protection Research 54:123-131.

McLean K.L., J. Hunt., dan A. Stewart. 2001. Compatibility of the Biocontrol Agent Trichoderma harzianum C52 with Selected Fungicides. New Zealand Plant Protection 54: 84-88.

Seema,M dan N.S. Devaki. 2012. In Vitro Evaluation of Biological Control Agents Against Rhizoctona solani. Journal of Agricurtural Technology 8:233-240.

Vey A., R.E. Hoagland., dan T.M. Butt. 2001. Toxic Metabolites of Fungal Biocontrol Agents. In: Butt T.M., C. Jackson. and N. Magan. (eds) Fungi as Biocontrol Agents Progress, Problem and Potenti. CABI publishing, Wallingford.

Widyastuti S.M. 1996. Penghambatan Penyakit Damping off (rebah semai) pada Semai Pinus dengan Ekstrak Biji Nyiri (Xylocarpus granatum). Jurnal Perlindungan Tanaman Indonesia 2, 1: 32-35

Zad S. dan M. Koshnevice. 2001. Damping-off in Conifer Seedling Nurseries in Noshahr and Kelardasht. Meded Rijksuniv Biological Journal 66: 91-93. 